\section{BIOLOGICAL ACTIVITIES OF NEWLY PREPARED SAFRAMYCINS}

\author{
Satoru Kaneda, Chen Hour-Young, \\ KaTSUKIYO YaZAWA, \\ KATSUHIRO TAKAHASHI, \\ YuzURU MiKami \\ and TADAshi ARAI
}

Department of Experimental Chemotherapy, Research Center for Pathogenic Fungi and Microbial Toxicoses,

Chiba University, 1-8-1 Inohana, Chiba 280, Japan

(Received for publication June 1, 1987)

We recently developed a method for directed biosynthesis of new saframycins using resting cells of Streptomyces lavendulae No. 314, a saframycin producer ${ }^{1)}$. Six new saframycins, i.e., Y3 Yd-1, Yd-2, Ad-1, Y2b and Y2b-d (Fig. 1) were prepared and their structures elucidated ${ }^{2)}$. Except for Ad-1, all the saframycins are characterized by an amino functional group in their side chain which is easily modifiable chemically or biochemically. In this paper, we report the biological activities, specifically the antimicrobial and cytotoxic activity of the saframycins.

All new saframycins were prepared in our laboratory by the directed biosynthetic method described in previous papers ${ }^{1,2}$. In brief, various amino acid analogs of the side chain were supplemented to the buffered-resting cells of the saframycin producer. Saframycins $\mathrm{Y} 3$ and $\mathrm{Y} 2 \mathrm{~b}$ were prepared by the addition of alanine, in addition to the usual saframycin compositions of tyrosine, methionine and glycine. Saframycins Yd-1, Ad-1 and Y2b-d were prepared by the addition of 2-amino- $n$-butyric acid and saframycin Yd-2 was prepared by adding glycylglycine. The antimicrobial spectra of new saframycins were determined by an agar dilution streak method. Nutrient agar including glucose $0.5 \%$ and 14 test microorganisms were used. Minimum inhibitory concentrations (MICs) were determined after 48 hours incubation at $37^{\circ} \mathrm{C}$. In vitro cytotoxic activity was determined using a

Fig. 1. Structures of newly prepared saframycins.

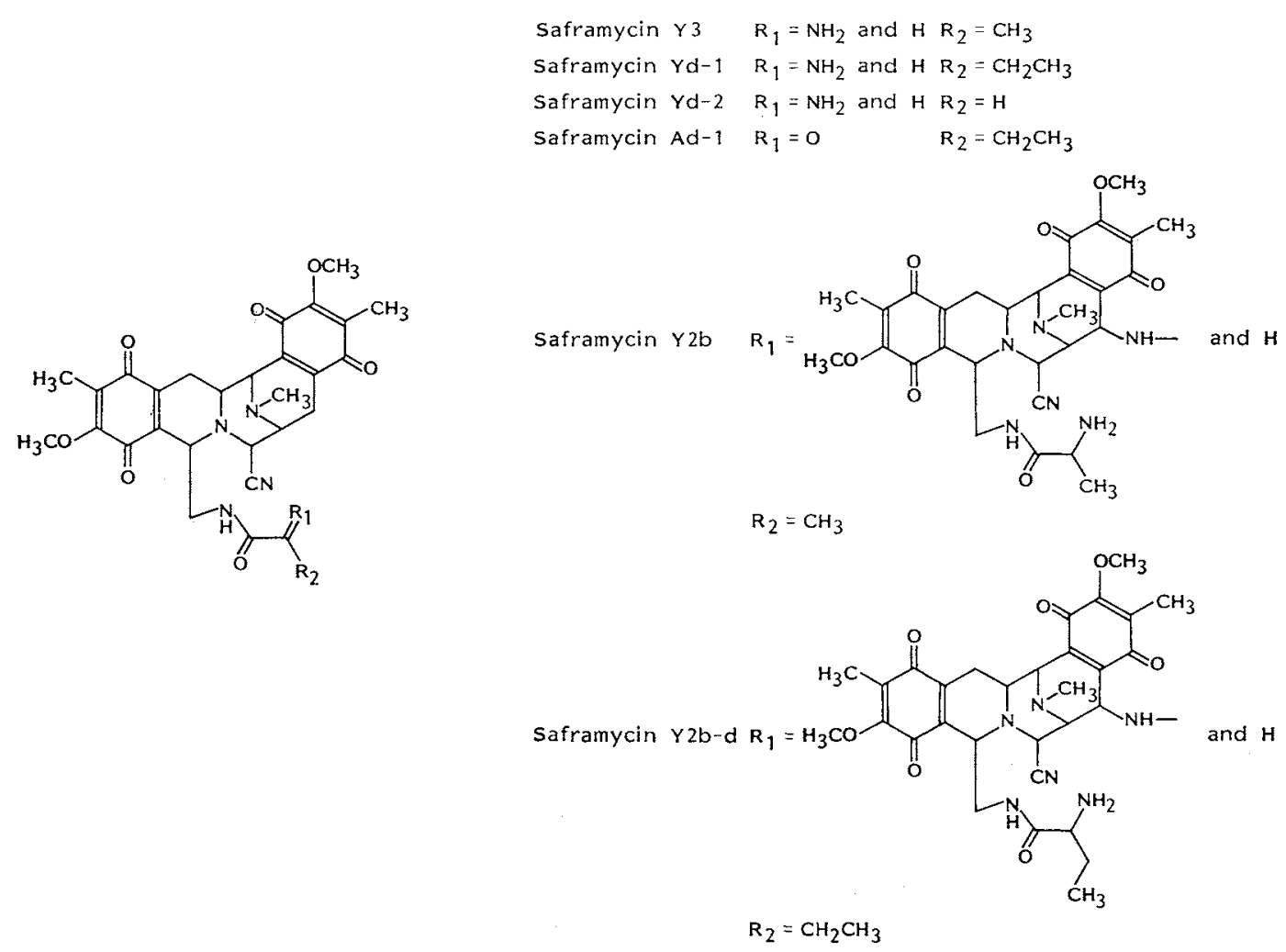


Table 1. Antimicrobial activities of newly prepared saframycins in comparison with that of saframycin A (MIC, $\mu \mathrm{g} / \mathrm{ml})$.

\begin{tabular}{lcrrrrrr}
\hline \multicolumn{1}{c}{ Organism } & $\mathrm{A}$ & \multicolumn{1}{c}{$\mathrm{Y3}$} & \multicolumn{1}{c}{ Y2b } & \multicolumn{1}{c}{ Yd-1 } & Ad-1 & Y2b-d & \multicolumn{1}{c}{ Yd-2 } \\
\hline Staphylococcus aureus 209P & 0.2 & 0.4 & 1.0 & 1.0 & 0.1 & 0.4 & 1.0 \\
S. albus & 0.78 & 0.4 & 1.0 & 1.0 & 1.0 & 0.4 & 1.0 \\
Micrococcus luteus & 3.12 & 0.4 & 1.0 & 1.0 & 1.0 & 0.78 & 1.0 \\
Streptococcus faecalis & 12.5 & 6.25 & 10.0 & 10.0 & 10.0 & 0.4 & 10.0 \\
S. pyogenes Cook & $<0.1$ & $<0.1$ & $<0.1$ & $<0.1$ & $<0.1$ & $<0.1$ & $<0.1$ \\
Bacillus subtilis PCI 219 & 6.25 & 12.5 & 1.0 & 1.0 & 1.0 & 0.4 & 10.0 \\
B. cereus & 12.5 & 50.0 & 25.0 & 50.0 & 50.0 & 50.0 & 100.0 \\
Mycobacterium sp. 607 & 25.0 & 100.0 & 25.0 & $>100.0$ & 50.0 & 25.0 & $>100.0$ \\
Nocardia asteroides & 12.5 & 25.0 & 50.0 & 50.0 & 50.0 & 50.0 & $>100.0$ \\
Escherichia coli F1 & $>100.0$ & 12.5 & 50.0 & 50.0 & 50.0 & 100.0 & 50.0 \\
Serratia marcescens & $>100.0$ & $>100.0$ & 50.0 & 50.0 & 100.0 & 100.0 & 50.0 \\
Pseudomonas aeruginosa & $>100.0$ & $>100.0$ & 50.0 & $>100.0$ & $>100.0$ & 50.0 & $>100.0$ \\
Brucella abortus & 0.4 & 0.78 & 0.78 & 1.0 & 10.0 & 3.12 & 10.0 \\
Candida albicans $7 \mathrm{~N}$ & $>100.0$ & $>100.0$ & 50.0 & $>100.0$ & $>100.0$ & 100.0 & $>100.0$ \\
\hline
\end{tabular}

cultured cell line of L1210 mouse leukemia. $\mathrm{ID}_{50}$ was determined as described in a previous paper ${ }^{3)}$.

The antimicrobial spectra are compared in Table 1 with that of saframycin A. New saframycins were active against most Gram-positive bacteria such as Staphylococcus aureus, Staphylococcus albus, Micrococcus luteus and Streptococcus pyogenes at the concentration of 0.1 $\mu \mathrm{g} / \mathrm{ml}$ to $1.0 \mu \mathrm{g} / \mathrm{ml}$. They were slightly active against Mycobacterium sp. 607 and Nocardia asteroides. However, all tested Gram-negative bacteria and fungi were insensitive, except for Brucella abortus. Although there were minor differences in their activities against some microorganisms, their antimicrobial spectra were very similar to that of saframycin A, which is the most active saframycin group antibiotic hitherto reported. Saframycin $Y 3$ is 25 -deoxy-25-aminosaframycin $A$, and saframycin Yd-1 is 25-deoxy-25-aminosaframycin Ad-1 ${ }^{2}$. Therefore, it was concluded that there are no differences in the activities of saframycin group antibiotics which have an amino group or a carbonyl group at C-25 position, although they greatly differ in their solubility and stability.

We had reported that the major antitumor activity of saframycin $\mathrm{A}$ is caused by covalent binding to duplex DNA and inhibition of its template activity ${ }^{4)}$. The Corey-Pauling Koltun (CPK) space filling model for the saframycin ADNA adduct was proposed ${ }^{43}$. According to the model, the activated form of the saframycin A molecule fits the minor groove of duplex DNA.
Table 2. Cytotoxic activities of newly prepared saframycins against L1210 leukemia in comparison with that of saframycin A.

\begin{tabular}{ll}
\hline \multicolumn{1}{c}{ Drugs } & ID $_{50}(\mu \mathrm{g} / \mathrm{ml})$ \\
\hline Saframycin A & 0.003 \\
Saframycin Y3 & 0.0025 \\
Saframycin Y2b & 0.0053 \\
Saframycin Yd-1 & 0.003 \\
Saframycin Ad-1 & 0.009 \\
Saframycin Y2b-d & 0.0074 \\
Saframycin Yd-2 & 0.042 \\
\hline
\end{tabular}

Therefore, it is reasonable to consider that modification in the side chain of saframycins with bulky substituents should result in a decrease in the activity. Structurally, saframycins Yd-1, Y3 and $\mathrm{Yd}-2$ are characterized by the presence of the 2-amino- $n$-butyryl-, alanyl- and glycyl group, respectively, in each side chain, as shown in Table 1 , although the antimicrobial activity of saframycin $\mathrm{Y} 3$ is slightly higher than that of saframycin Yd-1 or Yd-2. On the other hand, cytotoxic activities were different, with that of Yd-2 drastically reduced. These data suggest that either the longer or shorter side chain length results in a decrease in biological activity and support our previous hypothesis that the side chain of saframycins plays an important role in the manifestation of biological activity, although it is not essential for binding to $\mathrm{DNA}^{2)}$.

Since saframycin $Y 2 b$ is a dimer of saframycin $\mathrm{Y} 3$, and saframycin $\mathrm{Y} 2 \mathrm{~b}-\mathrm{d}$ is a dimer of saframycin Yd-1 as shown in Fig. 1, we were curious about the activities of these bulky dimeric safra- 
mycins. Interestingly, as shown in Table 1, no decrease in the activity of either dimer was observed. In addition, the possibility of the conversion of the dimers to monomer by enzymatic reaction was excluded by our preliminary experiments (data not shown). Detailed studies of these dimeric saframycins therefore are desired.

\section{References}

1) Arai, T.; K. Yazawa, K. Takahashi, A. Maeda \& Y. MIKamI: Directed biosynthesis of new saframycin derivatives with resting cells of Streptomyces lavendulae. Antimicrob. Agents Chemother. $28: 5 \sim 11,1985$
2) Yazawa, K.; K. Takahash, Y. Mikami, T. Arai, N. SaIto \& A. Kubo: Isolation and structural elucidation of new saframycins $\mathrm{Y} 3$, Yd-1, Yd-2, Ad-1, Y2b and Y2b-d. J. Antibiotics 39: 1639 1650, 1986

3) Kaneda, S.; C. Hour-Young, K. Yazawa, K. Takahashi, Y. Mikami \& T. ARaI: Antitumor activity of new semisynthetic saframycin derivatives. Jpn. J. Cancer Res. (Gann) 77: 1043 1049, 1986

4) Kishi, K.; K. YazaWa, K. Takahashi, Y. MIKAMI \& T. ARAI: Structure-activity relationships of saframycins. J. Antibiotics 37: 847 852, 1984 